\title{
Polynoidae (Annelida: Polychaeta) associated with cold-water coral reefs of the northeast Atlantic and the Mediterranean Sea
}

\author{
DIETER FIEGE ${ }^{1} \&$ RUTH BARNICH \\ Forschungsinstitut und Naturmuseum Senckenberg, Senckenberganlage 25, D-60325 Frankfurt/Main, Germany. E-mail: \\ Dieter.Fiege@senckenberg.de; Ruth.Barnich@senckenberg.de \\ ${ }^{\text {I}}$ Corresponding author
}

\begin{abstract}
An overview of polynoid scale worms known to occur on cold-water coral reefs of the northeast Atlantic and the Mediterranean Sea is given, including a key for identification of species. Harmothoe oculinarum (Storm, 1879), $H$. vesiculosa Ditlevsen, 1917, and Leucia violacea (Storm, 1879) comb. nov. are redescribed. A lectotype is designated for H. vesiculosa and the generic status of Leucia violacea (Storm, 1879) comb. nov. and Neolagisca jeffreysi (McIntosh, 1876) comb. nov. are changed. The biogeography of the species is discussed.
\end{abstract}

Key words: taxonomy, biogeography, Acanthicolepis, Harmothoe, Leucia, Neolagisca

\section{Introduction}

Cold-water coral reefs have long been known to local fishermen as productive fishing grounds especially in the Northeast (NE) Atlantic. Increasing exploitation of deep-water resources in recent years has raised awareness and subsequently shown that the extent and distribution of these reefs is apparently much wider than anticipated. They occur mainly in areas of enhanced primary productivity and water flow on the continental shelf edge, the continental slopes, and seamounts (Roberts 2005). Cold-water coral species, e.g., Lophelia pertusa (Linnaeus, 1758), a key structural species in the NE Atlantic, form a three-dimensional skeletal framework simultaneously providing niches for other species and hard substrate for the settlement of a wide variety of suspension feeding invertebrates (Rogers 1999). With about 1300 species reported from L. pertusa reefs in the NE Atlantic (Roberts et al. 2006), they are important biodiversity hotspots similar to shallow tropical warm-water coral reefs. Cold-water coral reefs of the Mediterranean Sea are impoverished in terms of coral species and associated fauna (Taviani et al. 2005, Zibrowius \& Taviani 2005), which can be explained by factors discussed elsewhere for the paucity of deep benthic Mediterranean fauna in general (e.g., Fredj \& Laubier 1985) and the polychaete taxa Serpulidae and Aphroditoidea in particular (Ben-Eliahu \& Fiege 1996; Barnich \& Fiege 2003).

Polychaeta as a key marine taxon, also plays a dominant role in diversity and abundance on coldwater coral reefs in the NE Atlantic. For example Jensen \& Frederiksen (1992) reported 1467 specimens of Polychaeta (31.7\% of the total fauna) comprising 67 taxa (22.5\% of all taxa) from $18.46 \mathrm{~kg}$ of life and dead L. pertusa from the Faroe Shelf. Polynoidae, a highly diverse and ubiquitous family of polychaetes, are motile predators/scavengers playing an important role in this peculiar habitat. Some species might even be restricted to cold-water coral reefs, since so far they 
have only been found associated with the respective coral species. Some of the species covered herein were studied by Loshamn (1980) in his unpublished thesis, which is available at the library of the University of Oslo. Although many aspects of his work are outdated, it is very valuable for anyone working on NE Atlantic scaleworms.

\section{Materials and methods}

The type material investigated herein has been loaned by the following institutions: Natural History Museum of the University of Oslo (ZMO), Science Museum of the University of Trondheim (VM), Zoological Museum, University of Bergen (ZMBN), and Zoological Museum, University of Copenhagen (ZMUC).

Additional material examined is deposited in the Senckenberg Museum Frankfurt (SMF) and in the collection of Francesco Mastrototaro, University of Bari (Italy).

In the "Material examined" sections, complete specimens are indicated by 'cs', while 'af', 'mf', and 'pf' refer to anterior, middle, and posterior fragments, respectively.

Specimens were studied using a stereomicroscope and a compound microscope equipped with Nomarski interference contrast. Drawings were made using a camera lucida. In the figures of anterior ends, the anteriormost elytra were either missing or removed. The description of elytral characters is based on anterior elytra if not indicated otherwise, since tubercles tend to disappear or be less prominent in posterior elytra.

Length $(\mathrm{L})$ is measured from the anterior margin of the prostomium to the posterior border of the last segment (the pharynx, if extended, is not included), and width (W) is taken at the widest segment, including parapodia but excluding chaetae.

\section{Results}

Acanthicolepis Norman in McIntosh, 1900

Type species: Polynoe asperrima M. Sars, 1861

Diagnosis. Body dorsoventrally flattened, short, with about 43 segments, more or less covered by elytra. Eighteen pairs of elytra on segments 2, 4, 5, 7, 9, 11, 13, 15, 17, 19, 21, 23, 26, 29, 32, 34, 35, and 38. Prostomium with distinct cephalic peaks and three antennae; lateral antennae inserted ventrally to median antenna; anterior pair of eyes dorsolateral on widest part of prostomium, posterior pair dorsal near hind margin of prostomium. Parapodia with elongate acicular lobes with both acicula penetrating epidermis; neuropodia with supra-acicular process. Notochaetae stout with numerous rows of spines; neurochaetae more slender with numerous rows of spines in distal region, tips unidentate and bidentate with subdistal secondary tooth.

\section{Acanthicolepis asperrima (M. Sars, 1861)}

Figure 1A-D

Polynoe asperrima M. Sars, 1861: 59.

Acanthicolepis asperrima: Barnich et al. 2000: 314, figs. 1, 2; Barnich \& Fiege 2003: 25, fig. 7A-L.

Acanthicolepis cousteaui Laubier, 1961: 1, figs. 1-3a,c.

Diagnosis. Eighteen pairs of elytra. Elytral margin with few fringing papillae, surface covered by 
spine-shaped tubercles with simple, bifid, or multifid tips, gradually becoming larger towards posterior margin, and with few papillae on posterior half (Fig. 1A-D).
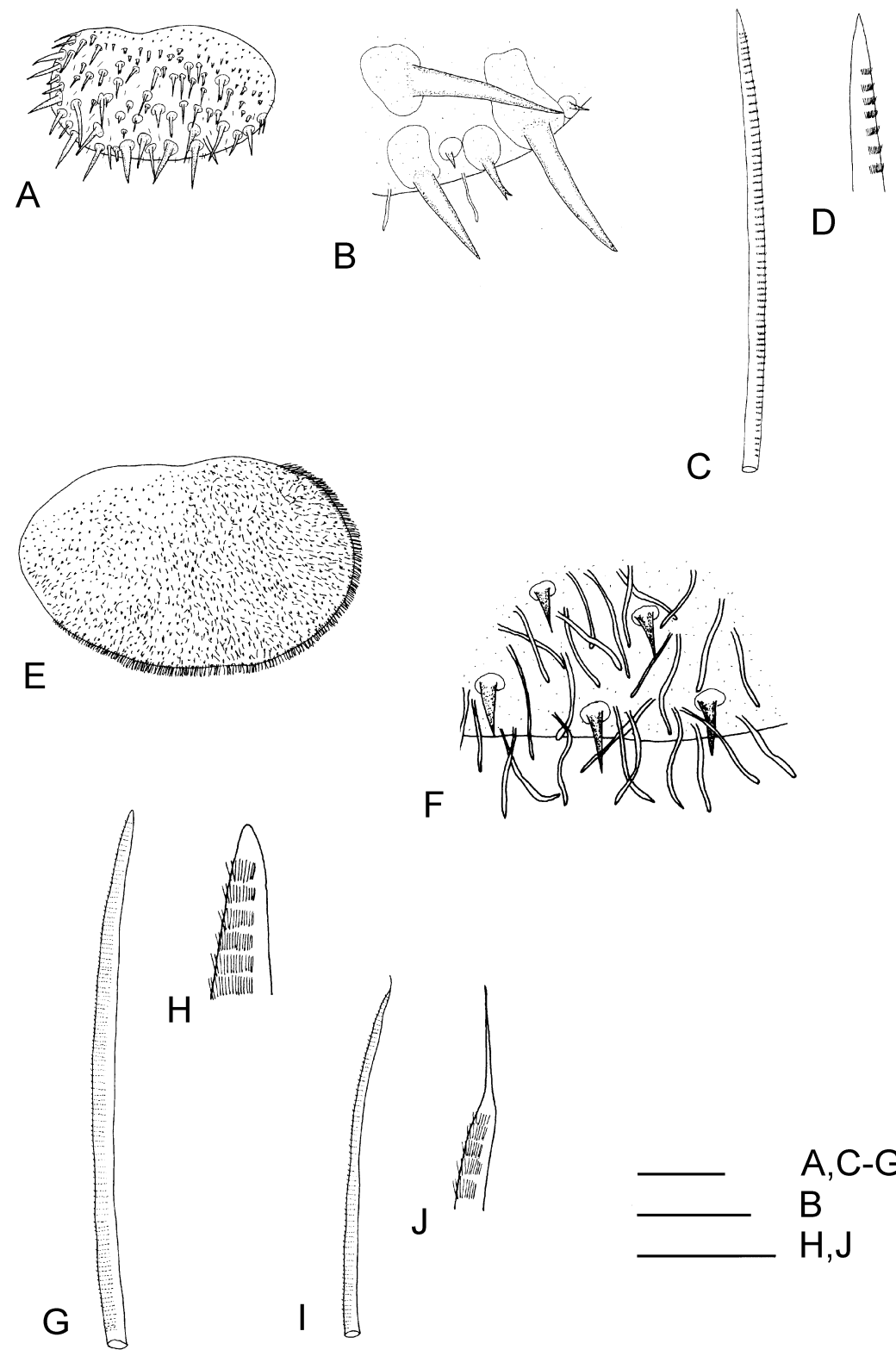

FIGURE 1. Diagnostic characters of Acanthicolepis asperrima (M. Sars, 1861) (A-D) and Neolagisca jeffreysi (McIntosh, 1876) comb. nov. (E-J). A, left anterior elytron; B, detail of margin of same; C, notochaeta; D, tip of same; E, right middle elytron; F, detail of posterior margin of same; G, stout notochaeta; $\mathrm{H}$, tip of same; I, slender notochaeta; J, tip of same. Scales: $1 \mathrm{~mm}$ for A, E; $250 \mu \mathrm{m}$ for B, C, G, I; $125 \mu \mathrm{m}$ for F; $50 \mu \mathrm{m}$ for D, H, J. 
Remarks. The genus Acanthicolepis was revised by Barnich et al. (2000), who considered A. asperrima as the only valid species, A. cousteaui Laubier, 1961 as a junior synonym, and A. equitis (McIntosh, 1885) as a doubtful species.

Habitat. On various hard substrates and also on the coral Madrepora oculata Linnaeus, 1758, in $15-1360 \mathrm{~m}$.

Distribution. NE Atlantic: from N Norway to the Azores; W Mediterranean Sea: from the Catalan coast to Monaco.

\section{Harmothoe Kinberg, 1856}

Type species: Harmothoe spinosa Kinberg, 1856

Diagnosis. Body dorsoventrally flattened, short, with up to about 50 segments; dorsum more or less covered by elytra or short posterior region uncovered. Fifteen pairs of elytra on segments 2, 4, 5, 7, $9,11,13,15,17,19,21,23,26,29$, and 32. Prostomium with distinct cephalic peaks and three antennae; lateral antennae inserted ventrally to median antenna. Position of anterior pair of eyes variable, posterior pair dorsal near hind margin. Parapodia with elongate acicular lobes with both acicula penetrating epidermis; neuropodia with a supra-acicular process. Notochaetae stout with distinct rows of spines and blunt tip. Neurochaetae more numerous, usually more slender, with distinct rows of spines distally and tips either all bidentate with a subdistal secondary tooth or some bi- and some unidentate.

\section{Harmothoe oculinarum (Storm, 1879)}

Figure 2A-I

Laenilla oculinarum Storm, 1879a: 33.

Polynoe oculinarum: Storm 1888: 85.

Harmothoe oculinarum: Levinsen 1884: 289; Bidenkap 1894: 47; Ditlevsen 1917: 30 (in part, only specimens from Trondheimfjord); Holthe 1977: 12; Loshamn 1980, unpublished thesis: 136, Fig. 66.

Material examined. ZMO C 5227: 2 cs, Trondheimfjord, coll. or det. Storm. ZMO C 5228: 3 af of H. oculinarum and 1 af of H. aspera (Hansen, 1879), Rødberg, coll. or det. Storm. ZMO C 5229: 3 cs, Trondheimfjord, 1892. ZMO C 5230: 2 cs, Trondheimfjord, coll. or det. C. Manthey. VM 58616: 3 af, 1 mf, 2 pf, Rødberg, Trondheimfjord, RV Gunnerus, St. 2006037, 63²8.093'N 959.9900'E, 250-180 m, 05.12.2006, coral fragments, triangular dredge, coll. \& det. T. Bakken. SMF 16983, 16984: $1 \mathrm{spm}$. in 2 vials (vial 1 with af \& $1 \mathrm{pf}$ in formalin/70\% ethanol; vial 2 with $1 \mathrm{mf}$ in $95 \%$ ethanol), Rødberg, Trondheimfjord, RV Gunnerus, Sta. 2006037, 63²8.093'N 959.9900'E, 250-180 m, 05.12.2006, on Lophelia, triangular dredge, coll. \& det. F. Pleijel. SMF 16985-16987: 3cs, Rødberg, Trondheimfjord, 300-500 m, 28.08.1990, on Lophelia, triangular dredge, coll. \& det. F. Pleijel. SMF 16990: $1 \mathrm{cs}, \varnothing \mathrm{kssund}$, Kalvholneset, RV Johan Ruud, Sta. 702, 68 $02.18^{\prime} \mathrm{N}$ $15^{\circ} 15.67^{\prime} \mathrm{E}, 454$ m, 24.09.2002, on Lophelia pertusa, triangular dredge, coll. C. d'Udekem d'Acoz.

Diagnosis. Anterior pair of eyes at widest part of prostomium. Fifteen pairs of elytra. Elytral surface and outer lateral and posterior margin densely covered by short papillae; patch of conical microtubercles present near anterior margin (missing in posterior elytra).

Description (Based on a well-preserved complete specimen, SMF 16990). Body with 41 segments. Prostomium bilobed, with distinct cephalic peaks (Fig. 2A); ceratophore of median antenna in anterior notch, lateral antennae inserted ventrally, styles of antennae papillate, tapering; 

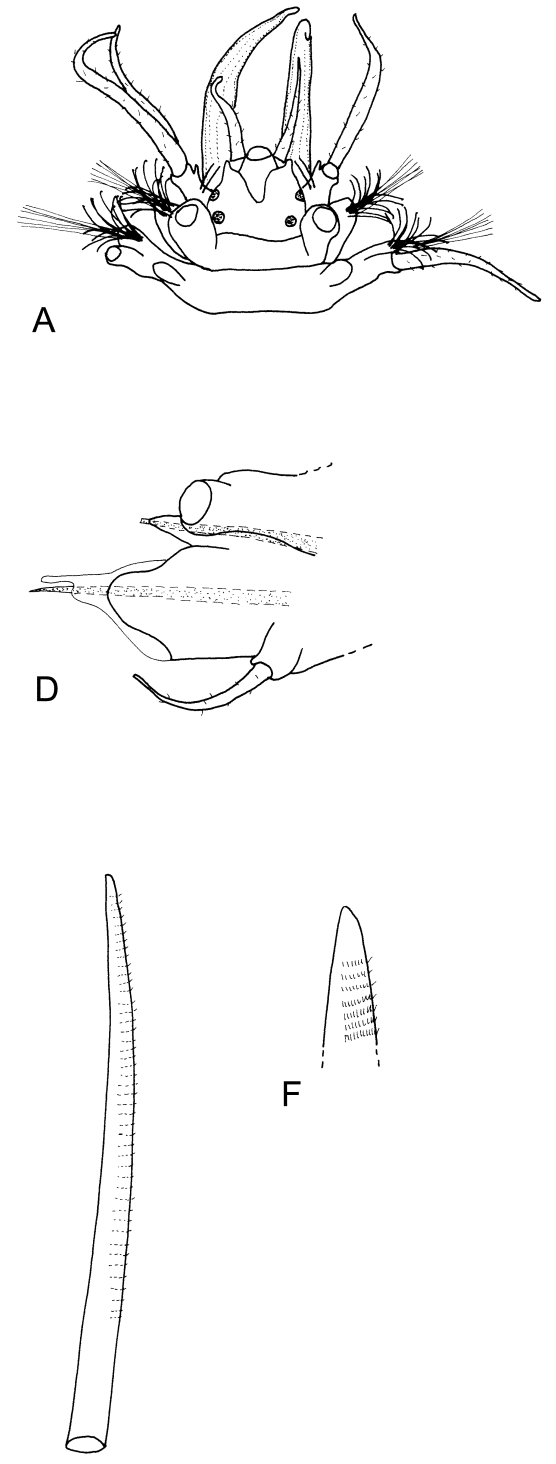

$\mathrm{E}$

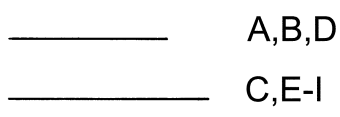

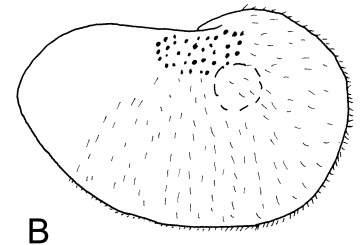
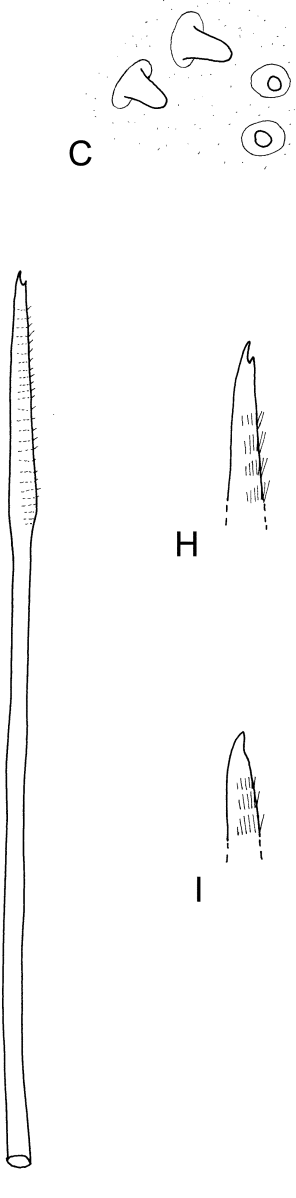

FIGURE 2. Harmothoe oculinarum (Storm, 1879), SMF 16990. A, anterior end, styles of median antenna, right dorsal tentacular cirrus, and left dorsal cirrus missing; B, left anterior elytron; C, microtubercles of same; D, left cirrigerous parapodium of segment 20, posterior view; E, long notochaeta; F, tip of same; G, middle neurochaeta; $\mathrm{H}$, tip of same; I, tip of lower neurochaeta. Scales: $2 \mathrm{~mm}$ for A, B; $1 \mathrm{~mm}$ for D; $250 \mu \mathrm{m}$ for C, E, G; $100 \mu \mathrm{m}$ for F, $\mathrm{H}-\mathrm{I}$. 
anterior pair of eyes dorsolateral at widest part of prostomium, posterior pair dorsal near hind margin, palps papillate, tapering.

Tentaculophores inserted laterally to prostomium, each with two notochaetae and a dorsal and ventral tentacular cirrus, styles of cirri papillate, tapering. Second segment with first pair of elytra, biramous parapodia, and long buccal cirri.

Fifteen pairs of elytra, covering dorsum, on segments $2,4,5,7$, then on every second segment to 23, 26, 29, and 32; last nine segments cirrigerous; elytral surface and outer lateral and posterior margin densely covered with short papillae; patch of conical microtubercles present near anterior margin (missing in posterior elytra). (Fig. 2B-C). Cirrigerous segments with distinct dorsal tubercles; dorsal cirri with cylindrical cirrophore, style papillate, tapering.

Parapodia biramous; notopodia with elongate acicular lobe; neuropodia with elongate prechaetal acicular lobe with digitiform supra-acicular process; neuropodial postchaetal lobe shorter than prechaetal lobe, rounded; tips of noto- and neuroacicula penetrating epidermis (Fig. 2D). Notochaetae stouter than neurochaetae; with distinct rows of spines and blunt tip (Fig. 2E-F); neurochaetae falcate, with distinct rows of spines distally; tip of neurochaetae mainly bidentate with stout secondary tooth, some lower neurochaetae with unidentate tips (Fig. 2G-I). Nephridial papillae distinct from segment 11 .

Color in life: body and elytra whitish, prostomium and prostomial appendages light pink.

Remarks. Although the species was not illustrated by Storm (1879a), the rather precise description of the elytra and the typical color of the body and elytra are sufficient to distinguish it from other Harmothoe species. Harmothoe oculinarum can easily be distinguished from $H$. vesiculosa, which also occurs on corals, by the presence of macrotubercles near the posterior margin in $H$. vesiculosa.

The specimens with the catalogue number ZMO C 5228 could be the type material but according to Storm (1879a) the type locality is Galgenes, belonging to the community of Rissen, near Rødberg in the Trondheimfjord; collecting location given on the accompanying label is indicated as Rødberg. Both locations are situated in the Trondheimfjord about $12 \mathrm{~km}$ apart from each other. Unfortunately, it was not possible to clarify the status of these specimens using Storm's catalogue which is kept in the Science Museum in Trondheim (pers. comm. T. Bakken).

Measurements. ZMO C 5228: 1 af, L 27mm, W $8 \mathrm{~mm}$ for 28 segments; 1 af, L $20 \mathrm{~mm}$, W $7 \mathrm{~mm}$ for 25 segments; 1 af, L $18 \mathrm{~mm}$, W $7 \mathrm{~mm}$ for 20 segments; additional specimen figured herein (SMF 16990): cs, L $26 \mathrm{~mm}$, W 6 mm for 41 segments; size range of other cs investigated herein: L 26-37 $\mathrm{mm}$, W 4-9 mm for 39-43 segments.

Habitat. Associated with cold water corals like Lophelia pertusa; in 50-500 m (Loshamn 1980, unpublished).

Distribution. NE Atlantic: along the Norwegian coast.

\section{Harmothoe vesiculosa Ditlevsen, 1917}

Figure 3A-J

Harmothoe vesiculosa Ditlevsen, 1917: 34, pl. 1, fig. 10, text figs. 16-17.

Type material. ZMUC-POL-1666: lectotype (1 af in rather bad condition, figured in Ditlevsen (1917) pl. 1 fig. 10, and designated as lectotype herein); ZMUC-POL-1857: 22 paralectotypes (21 af, $1 \mathrm{pf}$, and an indeterminable fragment of $H$. vesiculosa, all in rather bad condition; plus in a separate vial a possible flabelligerid); “Thor"-Expedition, $49^{\circ} 25^{\prime} \mathrm{N} 11^{\circ} 20^{\prime} \mathrm{W}, 1180 \mathrm{~m}, 25.06 .1905$, SW of 
Ireland (type locality situated on the Porcupine slope, known for its extensive coral reefs).

Additional material. SMF 16991: 1 spm., cs (in good condition), VITAL-Expedition, RV Atalante, St. V20 (ROV Victor dive 190), $46^{\circ} 15^{\prime} \mathrm{N} 4^{\circ} 42^{\prime} \mathrm{W}$, Bay of Biscay, Canyon de Belle Île, 1180 m, 01.09.2001, on Madrepora oculata, leg. H. Zibrowius. Univ. Bari (Italy): 2 spms., af (bad

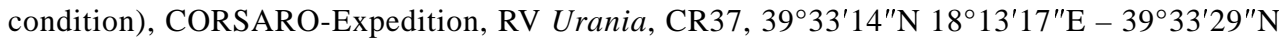
$18^{\circ} 13^{\prime} 08^{\prime \prime}$ E, Mediterranean Sea, Ionian Sea, off Santa Maria di Leuca, epibenthic sledge, 548-538 m, 30.04.2006, on Lophelia pertusa and Madrepora oculata.

Diagnosis. Anterior pair of eyes at widest part of prostomium. Fifteen pairs of elytra. Outer lateral and posterior elytral margin with short papillae; elytral surface with conical, blunt microtubercles; macrotubercles conical, blunt, in a dense row near posterior margin; macrotubercles rather small, but still distinctly larger than largest microtubercles.

Description. Since the type material is in poor condition, this description is based on a wellpreserved non-type specimen (SMF 16991).

Body with 41 segments. Prostomium bilobed, with prominent cephalic peaks (Fig. 3A); ceratophore of median antenna in anterior notch, lateral antennae inserted ventrally, styles of antennae papillate, tapering; eyes rather large, anterior pair dorsolateral at widest part of prostomium, posterior pair dorsal near hind margin of prostomium; palps papillate, tapering.

Tentaculophores inserted laterally to prostomium, each with two notochaetae and a dorsal and ventral tentacular cirrus, styles of cirri papillate, tapering. Second segment with first pair of elytra, biramous parapodia, and long buccal cirri.

Fifteen pairs of elytra, covering dorsum, on segments $2,4,5,7$, then on every second segment to 23, 26, 29, and 32; last nine segments cirrigerous; outer lateral and posterior elytral margin with short papillae; elytral surface with conical, blunt microtubercles; macrotubercles conical, blunt, in a dense row near posterior margin; macrotubercles rather small, but distinctly larger than largest microtubercles. (Fig. 3B-C). Cirrigerous segments with distinct dorsal tubercles; dorsal cirri with cylindrical cirrophore, style papillate, tapering.

Parapodia biramous; notopodia with elongate acicular lobe; neuropodia with elongate prechaetal acicular lobe with digitiform supra-acicular process; neuropodial postchaetal lobe shorter than prechaetal lobe, rounded; tips of noto- and neuroacicula penetrating epidermis (Fig. 3D). Notochaetae stouter than neurochaetae; notochaetae with distinct rows of spines and blunt tips (Fig. 3E-F); neurochaetae falcate, with distinct rows of spines distally; tip of neurochaetae mainly bidentate with slender secondary tooth (often abraded), some lower neurochaetae with unidentate tips (Fig. 3G-J). Nephridial papillae distinct from segment 6.

Remarks. Apart from the original description by Ditlevsen (1917), H. vesiculosa has been reported in three papers by Wesenberg-Lund (1950a, 1950b, 1953). From the remarks given in these papers it is clear that the author confused $H$. vesiculosa with H. imbricata (Linnaeus, 1767). While the elytra do show certain similarities in both species, they clearly differ by the position of the anterior pair of eyes which are situated dorsolaterally at the widest part of the prostomium in $H$. vesiculosa and anteroventrally beneath the cephalic peaks in $H$. imbricata. Moreover $H$. imbricata is a shallow-water species found in numerous habitats, whereas $H$. vesiculosa seems to be restricted to coral reefs in deeper waters. Thus, the specimens described here represent the first confirmed records of $H$. vesiculosa since its original description.

Harmothoe vesiculosa is easily distinguished from $H$. oculinarum (Storm, 1879), a species also found on cold water corals, by its elytral characters. In $H$. vesiculosa microtubercles are scattered over the elytral surface and macrotubercles are present in a dense row near the posterior margin. Whereas in $H$. oculinarum elytra have no macrotubercles and microtubercles are found only in a small patch near the anterior margin. 


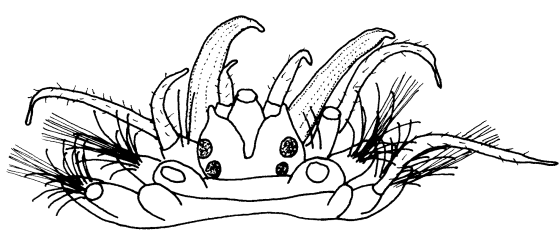

A
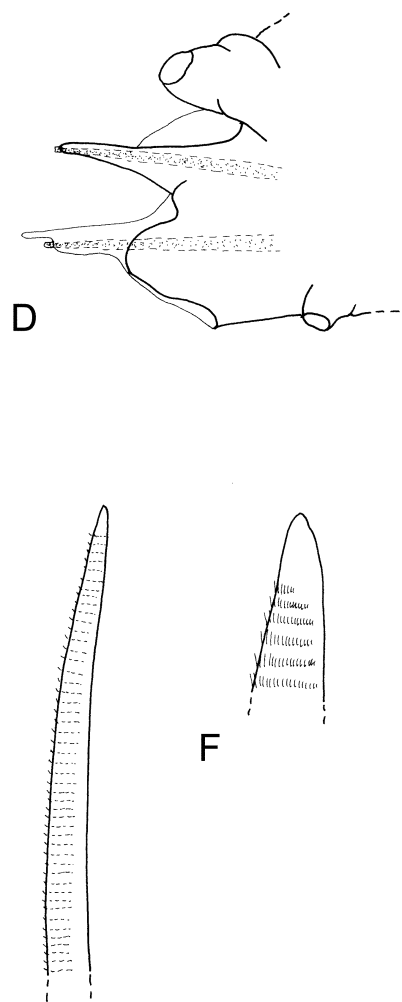

E

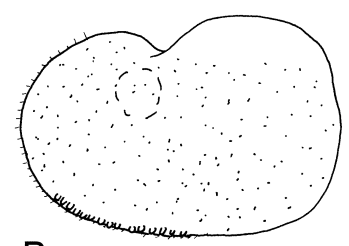

B
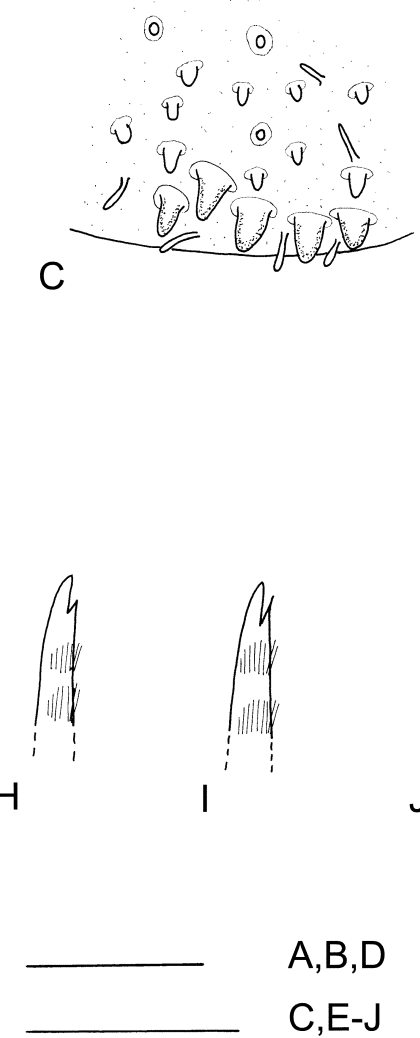

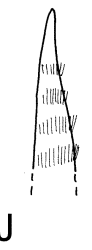

G

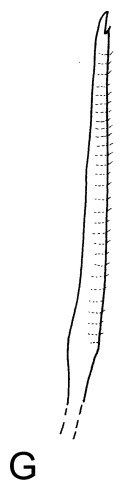

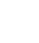

FIGURE 3. Harmothoe vesiculosa Ditlevsen, 1917, SMF 16991. A, anterior end, styles of median antenna, right dorsal tentacular cirrus, and left dorsal cirrus missing; B, right anterior elytron; C, detail of posterior margin of same; D, left cirrigerous parapodium of segment 16, posterior view; E, distal half of long notochaeta; F, tip of same; G, distal part of middle neurochaeta; H, tip of same; I, tip of upper neurochaeta; J, tip of lowermost neurochaeta. Scales: $2 \mathrm{~mm}$ for A, B; $1 \mathrm{~mm}$ for D; $250 \mu \mathrm{m}$ for C, E, G; $100 \mu \mathrm{m}$ for F, H-J.

Measurements. Lectotype (ZMUC-POL-1666): af, L $8 \mathrm{~mm}$, W $4 \mathrm{~mm}$, for 18 segments; additional specimen figured herein (SMF 18991): cs, L $24 \mathrm{~mm}, \mathrm{~W} 6 \mathrm{~mm}$ for 41 segments. 
Habitat. Associated with cold water corals like Lophelia pertusa and Madrepora oculata; in 538-1180 m.

Distribution. NE Atlantic: SW of Ireland (Porcupine slope) and Bay of Biscay (Canyon de Belle Île); Mediterranean Sea: Ionian Sea off Santa Maria di Leuca (S Italy).

Leucia Malmgren, 1867, Emended

Type species: Polynoe nivea Sars, 1863

Diagnosis. Body dorsoventrally flattened, short, with up to about 50 segments; dorsum more or less covered by elytra. Sixteen pairs of elytra on segments $2,4,5,7,9,11,13,15,17,19,21,23,26,29$, 32, and 35. Prostomium with distinct cephalic peaks and three antennae with lateral antennae inserted ventrally to median antenna. Anterior pair of eyes at widest part of prostomium, posterior pair dorsal near hind margin. Parapodia with elongate acicular lobes with both acicula penetrating epidermis; neuropodia with a supra-acicular process. Notochaetae stout with distinct rows of spines and blunt to pointed tip. Neurochaetae more numerous and more slender, with distinct rows of spines distally and bi- and unidentate tips.

Remarks. Leucia Malmgren, 1867, is closely related to Harmothoe Kinberg, 1856, the only difference being the number of pairs of elytra, which is 16 for Leucia and 15 for Harmothoe.

Leucia was established by Malmgren (1867) for Polynoe nivea Sars, 1863 and until now considered a monotypic genus. During the course of our revision of species assigned to Harmothoe in the NE Atlantic, we found a second species of Leucia, L. violacea (Storm, 1879) which also occurs on cold water corals; this species is redescribed below.

\section{Leucia violacea (Storm, 1879) comb. nov.}

Figure 4A-J

Laenilla violacea Storm, 1879a: 32; Storm 1879b: 124.

Harmothoe violacea: Bidenkap 1894: 47; Ditlevsen 1917: 34; Loshamn 1980, unpublished thesis: 175, fig. 87.

Evarne normani McIntosh, 1897: 168, 169, 178, pl. 3 fig. 13.

Type material. Laenilla violacea: VM 23903: 3 syntypes (1 cs in 2 fragments, 2 af, 1 mf; elytra all free in vial), Rødberg, Trondheimfjord. Evarne normani: BMNH ZB 1921.5.1.488: 1 syntype (af), Porcupine Expedition Cruise I, St. 3, 48 $31^{\prime} \mathrm{N} 10^{\circ} 3^{\prime} \mathrm{W}$, dredged, 8 July 1870, 690 fathoms (1262 m).

Additional material. ZMBN 4454: $1 \mathrm{spm}$. (1af, $2 \mathrm{mf}$, bad condition), labeled "Harmothoe violacea Storm," Trondheimfjord. The accompanying label is written in Storm's handwriting; therefore, this specimen possibly belongs to the type series of Laenilla violacea but was deposited separately in ZMBN. BMNH ZB 1921.5.1.489: 2 spms. (2 af, 3 mf, bad condition), labeled "Evarne normani," Norway, coll.? Canon Norman, 1879. These specimens could be syntypes of Evarne normani but collection data are insufficient to prove this. SMF 17298: $1 \mathrm{spm}$. (cs) and SMF 17299: 1 spm. (cs, juvenile, with 15 pairs of elytra only!), VITAL-Expedition, RV Atalante, St. V20 (ROV Victor dive 190), $46^{\circ} 15^{\prime} \mathrm{N} 4^{\circ} 42^{\prime} \mathrm{W}$, Bay of Biscay, Canyon de Belle Île, $1180 \mathrm{~m}, 01.09 .2001$, on Madrepora oculata, leg. H. Zibrowius.

Diagnosis. Sixteen pairs of elytra. Anterior half of elytra with numerous conical microtubercles; posterior half with rather indistinct, scattered, soft conical to mamilliform macrotubercles (absent in middle and posterior elytra); without or with few scattered papillae at margin or on surface. 


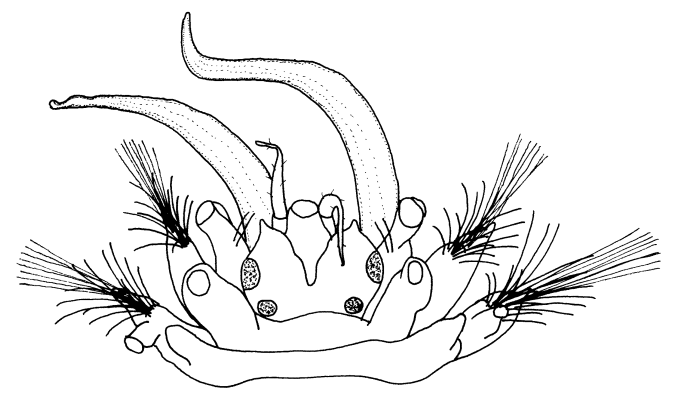

A
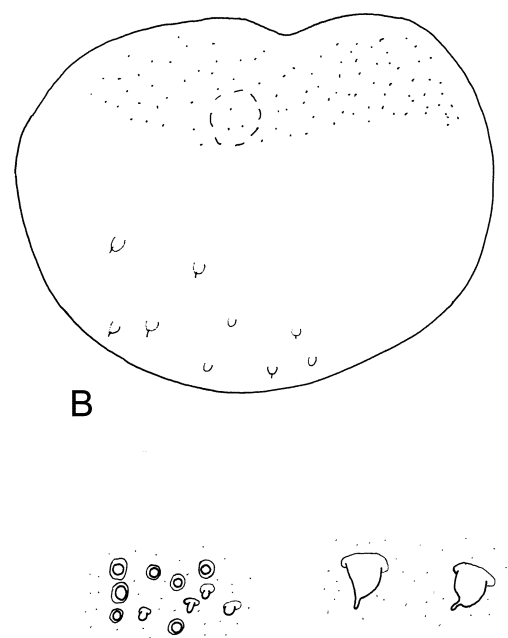

C

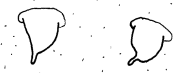

D

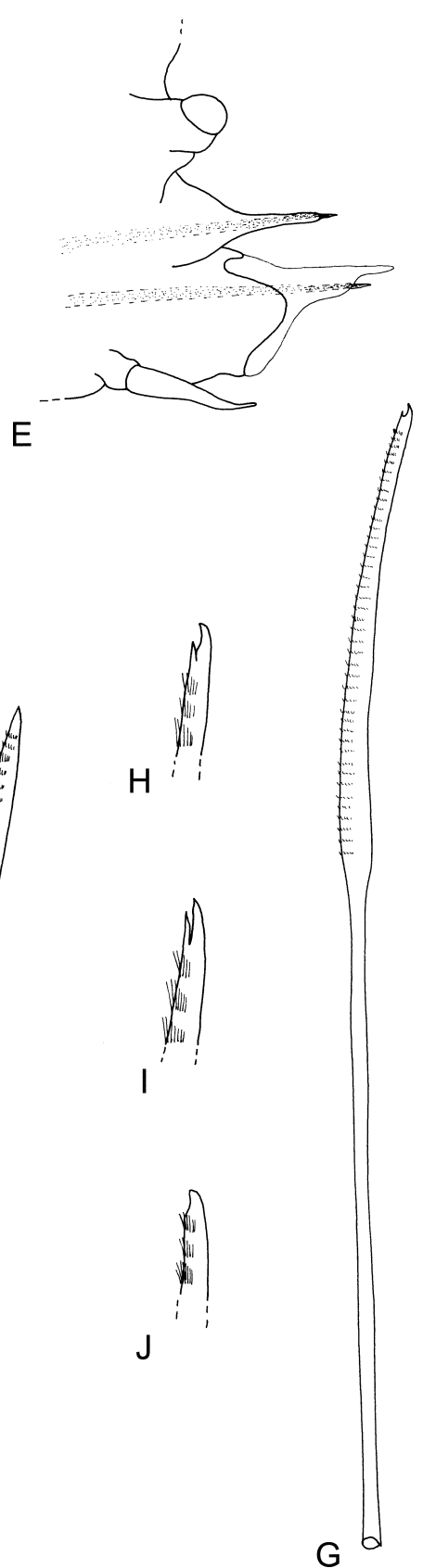

$\mathrm{F}$
A,B,E,H-J

$C, D, F, G$

FIGURE 4. Leucia violacea (Storm, 1879), syntype, VM 23903. A, anterior end, styles of median antenna, tentacular cirri, and dorsal cirri missing; B, left elytron from unknown segment; C, microtubercles; D, macrotubercles; E, right cirrigerous parapodium from unknown segment, posterior view; F, long notochaeta; , middle neurochaeta; $\mathrm{H}$, tip of same; I, tip of upper neurochaeta; J, tip of lowermost neurochaeta. Scales: $2 \mathrm{~mm}$ for A, B; $1 \mathrm{~mm}$ for E; $250 \mu \mathrm{m}$ for C, D, F, G; $50 \mu \mathrm{m}$ for $\mathrm{H}-\mathrm{J}$. 
Description (based on syntypes). Body with 42 segments. Prostomium bilobed, with distinct cephalic peaks (Fig. 4A); ceratophore of median antenna in anterior notch, lateral antennae inserted ventrally, styles of antennae papillate, tapering; anterior pair of eyes large, dorsolateral on widest part of prostomium, posterior pair dorsal near hind margin of prostomium; palps papillate, tapering.

Tentaculophores inserted laterally to prostomium, each with two notochaetae and a dorsal and ventral tentacular cirrus, styles of cirri papillate, tapering. Second segment with first pair of elytra, biramous parapodia, and long buccal cirri.

Sixteen pairs of elytra, covering dorsum, on segments $2,4,5,7$, then on every second segment to 23, 26, 29, 32 and 35; last seven segments cirrigerous; anterior half of elytra with numerous conical microtubercles; posterior half with rather indistinct, scattered, soft conical to mamilliform macrotubercles (absent in middle and posterior elytra); without papillae at margin or on surface (in additional specimens few, scattered marginal papillae present) (Fig. 4B-D). Cirrigerous segments with distinct dorsal tubercles; dorsal cirri with cylindrical cirrophore, style papillate, tapering.

Parapodia biramous; notopodia with elongate acicular lobe; neuropodia with elongate prechaetal acicular lobe with digitiform supra-acicular process; neuropodial postchaetal lobe shorter than prechaetal lobe, rounded; tips of noto- and neuroacicula penetrating epidermis (Fig. 4E). Notochaetae stouter than neurochaetae; notochaetae with distinct rows of spines and blunt to pointed tip (Fig. 4F); neurochaetae falcate, with distinct rows of spines distally; tip of neurochaetae mainly bidentate with stout secondary tooth, some lower neurochaetae with unidentate tip (Fig. 4G-J). Nephridial papillae distinct from segment 6.

Color in life: elytra pink to violet, body red to brown dorsally, white ventrally.

Remarks. Apart from the original description, the species is described and figured in detail by Loshamn (1980, unpublished). At that time the syntypes of Laenilla violacea were considered lost, but Loshamn examined several other specimens and noted the presence of 16 pairs of elytra. This was easily verified by us on the posterior fragment in the rediscovered type material deposited at the Science Museum in Trondheim and in one of the additional specimens listed above (SMF 17298) from the Bay of Biscay. Therefore we consider Laenilla violacea to belong to the genus Leucia Malmgren, 1867.

Leucia violacea comb. nov. is distinguished from L. nivea (Sars, 1863) by its elytral tubercles: in L. violacea microtubercles are all conical and macrotubercles are rather indistinct, scattered, soft conical to mamilliform, whereas in L. nivea microtubercles are conical, or distally bifid, or branched and macrotubercles are cylindrical to club-shaped and distally spinose (see also Chambers 1989).

Measurements. Syntypes of Laenilla violacea (VM 23903): cs (in two fragments; figured herein), L $42 \mathrm{~mm}$, W $9 \mathrm{~mm}$ for 42 segments; af, L $17 \mathrm{~mm}$, W $9 \mathrm{~mm}$ for 18 segments; af, L $8 \mathrm{~mm}$, W $7 \mathrm{~mm}$ for 16 segments.

Syntype of Evarne normani (BMNH ZB 1921.5.1.488): af, L 6 mm, W 6 mm for 16 segments.

Additional complete specimens: SMF 17298, cs, adult, L $27 \mathrm{~mm}$, W $6 \mathrm{~mm}$ for 44 segments; SMF 17299, cs, juvenile, L $15 \mathrm{~mm}$, W $3.5 \mathrm{~mm}$ for 36 segments.

Habitat. On hard substrates, often associated with cold water corals like Lophelia pertusa or Madrepora oculata; in 30-1262 m (see also Loshamn 1980, unpublished).

Distribution. NE Atlantic: along the Norwegian coast to the Bay of Biscay.

Neolagisca Barnich \& Fiege, 2000

Type species: Lagisca drachi Reyss, 1961

Diagnosis. Body flattened dorsoventrally, short, with up to 44 segments, more or less covered by 
elytra or short tail uncovered. Fifteen pairs of elytra on segments 2, 4, 5, 7, 9, 11, 13, 15, 17, 19, 21 , 23, 26, 29, and 32. Prostomium with distinct cephalic peaks and three antennae; lateral antennae inserted ventrally; anterior pair of eyes dorsolateral on widest part of prostomium, posterior pair dorsal near hind margin of prostomium. Parapodia with elongate acicular lobes with both acicula penetrating epidermis; neuropodia with supra-acicular process. Notochaetae of two kinds: stout with blunt tip and slender with sharp, pointed tip; both with distinct rows of spines; neurochaetae with distinct rows of spines only distally, tips bi- and unidentate.

Neolagisca jeffreysi (McIntosh, 1876) comb. nov.

Figure 1E-J

Lagisca jeffreysi McIntosh, 1876: 397, Pl. 71 Figs. 8-12, Pl. 73, figs. 17-18. Not Lagisca jeffreysi McIntosh, 1900 (homonym), now Malmgreniella mcintoshi (Tebble \& Chambers, 1982).

Lagisca drachi Reyss, 1961: 473, figs. 1, 2.

Neolagisca drachi: Barnich \& Fiege 2000:1932, fig. 20A-L; Barnich \& Fiege 2003:70, fig. 36A-L.

Diagnosis. Fifteen pairs of elytra; elytral margin with long fringing papillae; surface covered by pointed spine-shaped microtubercles and many long papillae. Notochaetae of two kinds: stout with blunt tip and slender with sharp, pointed tip (Fig. 1E-J).

Remarks. We are currently revising the NE Atlantic species of Harmothoe and realized that Lagisca jeffreysi McIntosh, 1876 shows exactly the same characters as described for Neolagisca drachi (Reyss, 1961) (see Barnich \& Fiege 2000). Our investigations on the syntypes of L. jeffreysi (BMNH 1921.5.1.309 and 1921.5.1.315) and the descriptions and figures given by McIntosh (1876) of the elytral (pl. 71 fig. 8) and chaetal characters (pl. 71 figs. 9-12 \& pl. 73 figs. 17-18) leave no doubt that Neolagisca drachi must be considered a junior synonym of Neolagisca jeffreysi comb. nov.

Hartman (1959) synonymized L. jeffreysi with Harmothoe extenuata (Grube, 1840); however, L. jeffreysi is not a Harmothoe species, because it shows two kinds of notochaetae while in Harmothoe only the kind with a blunt tip is found. Moreover, in H. extenuata microtubercles are never spineshaped, but conical and blunt; additionally, rounded macrotubercles are present, while they are lacking in N. jeffreysi.

Until now Neolagisca drachi was considered a Mediterranean endemic, but since $N$. jeffreysi was found during the Porcupine expeditions in $1869\left(43^{\circ} 49^{\prime} \mathrm{N} 13^{\circ} 15^{\prime} \mathrm{W}\right)$ and $1870\left(48^{\circ} 31^{\prime} \mathrm{N} 10^{\circ} 3^{\prime} \mathrm{W}\right)$ in the NE Atlantic, the species appears to be much more widely distributed.

Habitat. On muddy and sandy substrates (NE Atlantic) and also on the coral Madrepora oculata (Mediterranean); in 268-1256 m.

Distribution. NE Atlantic: W of Ireland and on the Channel slope; Western Mediterranean: off Banyuls-sur-mer in the Rech "Lacaze-Duthiers."

\section{Biogeographical remarks}

The distribution patterns of Harmothoe vesiculosa and Neolagisca jeffreysi comb. nov. appear disjunct since the two species have only been found in the W Mediterranean (off Cape Sta. Maria di Leuca; Rech "Lacaze Duthiers") and at some locations in the NE Atlantic (SW of Ireland, Bay of Biscay; W of Ireland and Channel slope), leaving a large gap in between. In both areas extensive deep-water coral reefs are known to exist (Rogers 1999; DeMol et al. 2002; Taviani et al. 2005). De 
Mol et al. (2005) suggest a simultaneous start for the development of coral banks in the NE Atlantic in a time-period following the late Pliocene. These authors hypothesize that the Mediterranean Outflow Water (MOW) - a current flowing at mid-depth from Gibraltar northward along the European continental margin to the Porcupine Bank (van Aken 2000, New et al. 2001)—carries larvae of deep-water corals and initiates colonies of these corals along its way including the formation of extensive coral banks in the Porcupine Bight. Free-swimming larvae of species associated with deep-water corals in the Mediterranean Sea could likewise be disseminated along the same route by the MOW. This might not only explain the known distribution of the above-mentioned polynoid species, but would suggest their possible occurrence on additional deep-water corals along the European continental margin. The fact that currently known Mediterranean and Atlantic records are found at similar depths supports a possible distribution by the MOW. The implication, however, that the Mediterranean Sea might act as origin and reservoir for NE Atlantic deep-water coral reefs and their associated fauna is unproven (De Mol et al. 2005). Moreover, it appears to contradict the observation that the recent Mediterranean fauna evolved mainly by restocking from the NE Atlantic during the Pliocene and Pleistocene.

Harmothoe oculinarum appears to be restricted to the Norwegian coast, while Leucia violacea and Acanthicolepis asperrima are widely distributed from the Bay of Biscay and Azores, respectively, to northern Norway.

\section{Key to polynoids known to occur on cold-water corals}

1. Elytral tubercles spine-shaped.

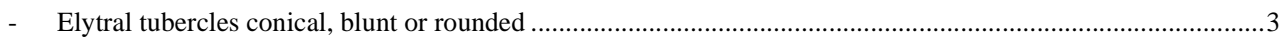

2. Elytral surface covered by spine-shaped tubercles with simple, bifid, or multifid tips, becoming gradually larger towards posterior margin, and by few papillae on posterior half; elytral margin with few fringing papillae; 18 pairs of elytra. Notochaetae of one kind: stout with slightly pointed tip

Acanthicolepis asperrima (Fig. 1A-D)

- Elytral surface covered by spine-shaped microtubercles with simple tip and by many long papillae; elytral margin with long fringing papillae; 15 pairs of elytra. Notochaetae of two kinds: stout with blunt tip and slender with sharp, pointed tip.....

Neolagisca jeffreysi (Fig. 1E-J)

3. Elytral margin and surface without papillae; anterior half of elytra with numerous conical microtubercles; posterior half with rather indistinct, scattered, soft conical to mamilliform macrotubercles; 16 pairs of elytra........ Leucia violacea (Fig. 4B-D)

- Elytral margin and surface with short papillae; shape and distribution of elytral tubercles otherwise...............4

4. Elytral surface densely covered by short papillae; patch of conical microtubercles present near anterior margin (missing in posterior elytra); 15 pairs of elytra .Harmothoe oculinarum (Fig. 2B-C)

- Elytral surface with papillae mostly near lateral and posterior margin, surface covered with conical, blunt microtubercles; macrotubercles conical, blunt, in a dense row near posterior margin; 15 pairs of elytra

Harmothoe vesiculosa (Fig. 3B-C)

\section{Acknowledgements}

We would like to thank Fredrik Pleijel (Tjärnö), Cédric d'Udekem d'Acoz (Tromsö), and Helmut Zibrowius (Marseille) for making freshly collected and well-preserved specimens available to us for study and for depositing them in the Senckenberg collections. Tor Bakke (Oslo), Torkild Bakken (Trondheim), Danny Eibye-Jacobsen (Copenhagen), Jon Anders Kongsrud (Bergen), and Francesco 
Mastrototaro (Bari) are thanked for loans of specimens from their respective collections. Figures of Neolagisca jeffreysi have been published previously in the Journal of Natural History (Taylor \& Francis Ltd.).

\section{References}

Barnich, R. \& Fiege, D. (2003) The Aphroditoidea (Annelida: Polychaeta) of the Mediterranean Sea. Abhandlungen der Senckenbergischen Naturforschenden Gesellschaft, 559, 1-167.

Barnich, R. \& Fiege, D. (2000) Revision of the Mediterranean species of Harmothoe Kinberg, 1856 and Lagisca Malmgren, 1865 (Polychaeta: Polynoidae: Polynoinae) with descriptions of a new genus and a new species. Journal of Natural History, 34, 1889-1938.

Barnich, R., Gil. J. \& Fiege, D. (2000) Revision of the genus Acanthicolepis Norman in McIntosh, 1900 (Polychaeta: Polynoidae: Polynoinae). Sarsia, 85, 313-319.

Ben-Eliahu, M.N. \& Fiege, D. (1996) Serpulid tube-worms (Annelida: Polychaeta) of the Central and Eastern Mediterranean with particular attention to the Levant Basin. Senckenbergiana maritima, 28(1-3), 1-51.

Bidenkap, O. (1894) Systematisk oversigt over Norges Annulata Polychaeta. Christiania Videnskabs-Selskabs Forhandlinger, 10, 1-142.

Chambers, S. (1989) Leucia nivea: A polynoid (Polychaeta) new to the British Isles. Irish Natural History Journal, 23(4), 145-147.

De Mol, B., Henriet, J.-P. \& Canals, M. (2005) Development of coral banks in Porcupine Seabight: do they have Mediterranean ancestors?. In: Freiwald, A. \& Roberts, J. M. (Eds.), Cold-water corals and ecosystems. Springer Verlag, Berlin, pp. 515-533.

DeMol, B., Van Rensbergen, P., Pillen, S., Van Herreweghe, K., Van Rooij, D, McDonnell, A., Huvenne, V., Ivanov, M., Swennen \& R., Henriet, J.-P. (2002) Large deep-water coral banks in the Porcupine Basin, southwest of Ireland. Marine Geology, 188, 193-231.

Ditlevsen, H. (1917) Annelids. The Danish Ingolf Expedition, 4 (Part 4), 1-71.

Fredj, G. \& Laubier, L. (1985) The deep Mediterranean benthos. In: Moraitou-Apostolopoulou, M. \& Kiortsis, V. (Eds.), Mediterranean Marine Ecosystems. Plenum Press, New York, pp. 109-145.

Grube, E. (1840) Actinien, Echinodermen und Würmer des Adriatischen- und Mittelmeers nach eigenen Sammlungen beschrieben. Bon, Königsberg, 92 pp.

Hansen, G.A. (1879) Annelider fra den norske Nordhavexpedition i 1876. Nyt Magasin for Naturvidenskaberne, 24(1), 1-14.

Hartman, O. (1959) Catalogue of the polychaetous annelids of the world. Part. I. Allan Hancock Foundation Publications, Occasional Papers, 23, 1-353.

Holthe, T. (1977) The polychaetous annelids of Trondheimsfjorden, Norway. Gunneria, 29, 1-64.

Jensen, A. \& Frederiksen, R. (1992) The fauna associated with the bank-forming deepwater coral Lophelia pertusa (Scleractinaria) on the Faroe shelf. Sarsia, 77, 53-69.

Kinberg, J.G.H. (1856) Nya slägten och arter af Annelider. Öfversigt af Kongliga Vetenskaps-Akademiens Förhhandlingar, 12(9-10), 381-388 [read 1855; printed 1856].

Laubier, L. (1961) Acanthicolepis cousteaui n. sp., un Aphroditien de profondeur récolté par la soucoupe plongeante. Bulletin de l'Institut Océnographique, 1221, 1-12.

Levinsen, G.M.R. (1884) Systematisk-geografisk-Oversigt over de nordiske Annulata, Gephyrea, Chaetognathi og Balanoglossi. II. Videnskabelige Meddelelser fra den naturhistorisk Forening i Kjøbenhavn, 92-350.

Linnaeus, C. (1758) Systema naturae, per regna tria naturae, secundum classes, ordines, genera, species, cum characteribus, differentiis, synonymis, locis (10th edition). Tomus I. Laurentii Salvii, Holmiae, 824 pp.

Linnaeus, C. (1767) Systema naturae, per regna tria naturae, secundum classes, ordines, genera, species, cum characteribus, differentiis, synonymis, locis (12th edition). Tomus I, Pars II. Laurentii Salvii, Holmiae, 
533-1327 pp.

Loshamn, A.A. (1980) En systematisk og dyregeografisk Undersökelse over Skjellrygg-Gruppen (Familie Aphroditidae sensu Fauvel 1923). Dissertation. Zoologisk Institutt, Universitete i Oslo, 184 pp. (unpublished).

Malmgren, A.J. (1867) Annulata polychaeta Spetsbergiae, Groenlandiae, Islandiae et Scandinaviae hactenus cognita. Öfversigt af Kongliga Vetenskaps-Akademiens Förhhandlingar, 24, 127-235.

McIntosh, W.C. (1876) On the Annelida of the 'Porcupine' Expeditions of 1869 and 1870. Part I. - Euphrosynidae, Amphinomidae, Aphroditidae, Polynoidae, Acoetidae, and Sigalionidae. Transactions of the Zoological Society, London, 9, 395-416.

McIntosh, W.C., (1885) Report on the Annelida Polychaeta collected by H.M.S. Challenger during the years 1873-76. Reports on the scientific results of the voyage of H.M.S. Challenger, Zoology, 12, 1-554.

McIntosh, W.C. (1897) Notes from the Gatty Marine Laboratory, St. Andrews, No. XVIII. 1. On the phosphorescence of Gattyana (Nychia) cirrosa Pallas. 2. On a new Evarne (E. atlantica) from Rockall. 3. On the British species of Pholö̈. 4. On a collection of annelids made by Canon Norman in Norway. - Part I, new Evarne and two species of Sthenelais. Annals and Magazine of Natural History London, Series 6, 20, $167-178$.

McIntosh, W.C. (1900) A Monograph of the British Annelids. Part II. Polychaeta. Amphinomidae to Sigalionidae. Ray Society, London, 215-442 pp.

New, A.L., Barnard, S., Herrmann, P. \& Molines, J.M. (2001) On the origin and pathway of the saline inflow to the Nordic Seas: insight from models. Progress in Oceanography, 48, 255-287.

Reyss, D. (1961) Lagisca drachi, n. sp., polychète Aphroditidae récoltée dans le Rech Lacaze-Duthiers. Vie et Milieu, 12(3), 473-481.

Roberts, J.M. (2005) Reef-aggregating behaviour by symbiotic eunicid polychaetes from cold-water corals: do worms assemble reefs? Journal of the Marine Biological Association of the United Kingdom, 85, 813-819.

Roberts, J.M., Wheeler, A.J. \& Freiwald, A. (2006) Reefs of the deep: the biology and geology of cold-water coral ecosystems. Science, 312(5773), 543-547.

Rogers, A.D. (1999) The biology of Lophelia pertusa (Linnaeus, 1758) and other deep-water reef-forming corals and impacts from human activities. Internationale Revue der gesamten Hydrobiologie und Hydrographie, 84(4), 315-406.

Sars, M. (1861) Om de ved Norges Kyster forekommende Arter af Annelideslaegten Polynö̈. Christiania Videnskabs-Selskabs Forhandlinger, 54-62.

Sars, M. (1863) Geologiske og zoologiske iagttagelser, anstillede paa en Reise i en Deel af Trondhjems Stift i Sommeren 1862. II. Zoologiske Notitser fra Christiansund og Bejan. Nyt Magazin for Naturvidenskaberne, 12, 273-340.

Storm, V. (1879a) Bidrag til Kundskab om Throndhjemsfjordens Fauna. Det Kongelige Norske Videnskabers Selskabs Skrifter, 9-36.

Storm, V. (1879b) Bidrag til Kundskab om Throndhjemsfjordens Fauna. Det Kongelige Norske Videnskabers Selskabs Skrifter, 109-125.

Storm, V. (1888) Direktionens Aarsberetning for 1887. Det Kongelige Norske Videnskabers Selskabs Skrifter, 77-90.

Taviani, M., Freiwald, A. \& Zibrowius, H. (2005) Deep coral growth in the Mediterranean Sea: an overview. In: Freiwald, A. \& Roberts, J. M. (Eds.), Cold-water corals and ecosystems. Springer Verlag, Berlin, pp. 807-819.

Tebble, N. \& Chambers, S. (1982) Polychaetes from Scottish waters. Part 1. Family Polynoidae. Royal Scottish Museum Studies, 1-73.

van Aken, H.M. (2000) The hydrography of the mid-latitude Northeast Atlantic Ocean II: The intermediate water masses. Deep-Sea Research I, 47, 789-824.

Wesenberg-Lund, E. (1950a) Polychaeta. The Danish Ingolf-Expedition, 4 (Part 14), 1-92.

Wesenberg-Lund, E. (1950b) The Polychaeta of West Greenland with special reference to the fauna of Nordre Strømfjord, Kvane-, and Bredefjord. Meddelelser om Grønland, 151(2), 1-171.

Wesenberg-Lund, E. (1953) The Zoology of East Greenland. Polychaeta. Meddelelser om Grønland, 122(3), $1-169$. 
Zibrowius, H. \& Taviani, M. (2005) Remarkable sessile fauna associated with deep coral and other calcareous substrates in the Strait of Sicily, Mediterranean Sea. In: Freiwald, A. \& Roberts, J. M. (Eds.) Cold-water corals and ecosystems. Springer Verlag, Berlin, pp. 807-819. 